\title{
Peer Review of "Evaluating Population Density as a Parameter for Optimizing COVID-19 Testing: Statistical Analysis"
}

\author{
Ayman A Allam, MD \\ Faculty of Medicine, Zagazig University, Zagazig, Egypt \\ Related Articles: \\ Preprint: https://preprints.jmir.org/preprint/22195 \\ Author Responses to Peer-Review Reports: https://med.jmirx.org/2021/1/e27258/ \\ Published Article: https://med.jmirx.org/2021/1/e22195/
}

(JMIRx Med 2021;2(1):e27257) doi: 10.2196/27257

\section{KEYWORDS}

infectious diseases; COVID-19; SARS-CoV2; coronarvirus

This is a peer review submitted for the paper "Evaluating Population Density as a Parameter for Optimizing COVID-19 Testing: Statistical Analysis.”

\section{Round 1 Review}

\section{General Comments}

In this paper [1], the authors prospectively analyzed COVID-19 data obtained from 67 Alabama counties using testing realignment along population density instead of density agnostic per capita. They concluded that adjusting the distribution of testing capacity to also account for population density will improve monitoring and response to blunt the speed and spread of the virus.

Generally, the manuscript is properly structured and well understood.

\section{Specific Comments}

\section{Minor Comments}

1. Change the subtitle "Policy Proposal" to "Introduction" or "Background."

\section{Conflicts of Interest}

None declared.

\section{Reference}

1. Budhwani KI, Budhwani H, Podbielski B. Evaluating Population Density as a Parameter for Optimizing COVID-19 Testing: Statistical Analysis. JMIRx Med 2021;2(1):e22195. [doi: 10.2196/22195]

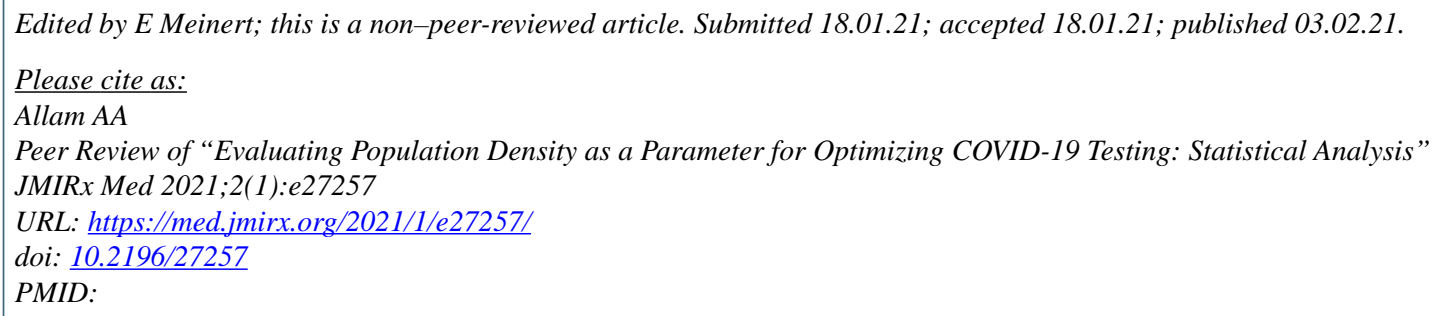

CAyman A Allam. Originally published in JMIRx Med (https://med.jmirx.org), 03.02.2021. This is an open-access article distributed under the terms of the Creative Commons Attribution License (https://creativecommons.org/licenses/by/4.0/), which permits unrestricted use, distribution, and reproduction in any medium, provided the original work, first published in JMIRx Med, is properly cited. The complete bibliographic information, a link to the original publication on https://med.jmirx.org/, as well as this copyright and license information must be included. 